\title{
Biomonitoring of selected freshwater macrophytes to assess lake trace element contamination: a case study of Nal Sarovar Bird Sanctuary, Gujarat, India
}

\author{
J.I. Nirmal KUMAR ${ }^{1 \#^{*}}$, Hiren SONI ${ }^{1)}$ and Rita N. KUMAR ${ }^{2)}$ \\ ${ }^{1)}$ Head, P.G. Department of Environmental Sciences, Institute of Science \& Technology for Advanced Studies \& Research (ISTAR), \\ Vallabh Vidyanagar - 388 120, Gujarat, India \\ ${ }^{2)} \mathrm{Head}$, Department of Biosciences \& Environmental Sciences, N.V. Patel College of Pure \& Applied Sciences, Vallabh Vidyanagar \\ - 388 120, Gujarat, India \\ *e-mail corresponding author: istares2005@yahoo.com
}

\begin{abstract}
A biomonitoring study was carried out at Nal Sarovar Bird Sanctuary, a proposed Ramsar site, Gujarat State, India, to ascertain the degree of trace element contamination. The study focused on assessment of trace element contamination in certain aquatic macrophytes to be used as biomonitors, in comparison with the sediments (abiotic monitor) for heavy metal pollution. Good information was provided by analyzing roots, stems and leaves of native aquatic plants (biomonitors) represented by eight species: Bergia odorata, Hydrilla verticillata, Ipomoea aquatica, Najas graminea, Nelumbo nucifera, Phragmites karka, Typha angustata and Vellisnaria spiralis, alongwith surface sediments and water, were analyzed for $\mathrm{Cd}, \mathrm{Co}, \mathrm{Cu}, \mathrm{Cu}, \mathrm{Ni}, \mathrm{Pb}$ and $\mathrm{Zn}$ contamination. The highest concentrations of the trace elements were measured in Ipomoea aquatica and the lowest in Bergia odorata. Based on the concentration and toxicity status observed in the lake's vegetation, the six metals are arranged in the following decreasing order: $\mathrm{Zn}$ $>\mathrm{Cu}>\mathrm{Ni}>\mathrm{Co}>\mathrm{Pb}>\mathrm{Cd}$. Compared with the standard, normal and critical toxicity range in plants, the detected values of $\mathrm{Cd}$ and $\mathrm{Pb}$ falls within normal range, while that of $\mathrm{Co}, \mathrm{Ni}$ and $\mathrm{Cu}$ were within the critical range. However, Zn showed the highest concentration and alarming toxicity levels, which is considered as one of the most hazardous pollutants in Nal Sarovar Bird Sanctuary. Certain aquatic macrophytes species are also proposed as biomonitors for the investigated heavy metal pollutants. Such result was significant in the plant species such as Ipomoea aquatica and Phragmites karka, which are the two most useful species in biomonitoring studies due to their ability to accumulate elements in high concentration in the roots and their availability throughout the year. The results showed the significant difference in accumulation rate of some metals like $\mathrm{Zn}$, Cu and Ni in different plant organs, which showed more accumulation in root than that of stem and leaves. Also, there is a high positive correlation between combinations of different metal-pairs in either plant's root, stem or leaf system.
\end{abstract}

Key words: freshwater macrophytes, trace element, contamination, Nal Sarovar Bird Sanctuary

\section{INTRODUCTION}

Direct discharge or wet and dry depositions of contaminants increase the concentrations of trace elements of aquatic systems, thus resulting in their accumulation in sediments (Dunbabin \& Bowmer 1992; Sinicrope et al. 1992). Aquatic plants absorb elements through roots and/or shoots (Pip \& Stepaniuk 1992; Jackson 1998). Various species show different behaviour regarding their ability to accumulate elements in roots, stems and/or leaves. Therefore, it is useful to identify the plant organ that absorbs the greatest amount of trace elements (Baldantoni et al. 2004). In aquatic systems, where pollutant inputs are discontinuous and pollutants are quickly diluted, analyses of plant tissues provide timeintegrated information about the quality of the system (Baldantoni et al. 2005).

Biomonitoring has several advantages and is the most significant-one in study of sublethal levels of bioaccumulated contaminants within the tissues of organisms, which indicate the net amount of pollutants integrated over a period of time (Lovett-Doust et al. 1994). Biomonitoring of pollutants using some plants as accu- mulator species, which accumulate relatively large amounts of certain pollutants, even from very diluted solutions without obnoxious effects (Ravera et al. 2003). It may be performed in two ways, based on the kind of sampled organisms: i) "endemic" or native organisms (passive biomonitoring) and ii) introduced organisms (active biomonitoring) (Chaphekar 1991).

Rana \& Nirmal Kumar (1988) observed heavy metal content through EDAX in certain sediments of Central Gujarat and noticed that $\mathrm{Fe}$ content was highest in sediments of Undeva, followed by $\mathrm{Si}$ and Al. Nirmal Kumar et al. (1989) have investigated elemental composition of certain aquatic plants of Central Gujarat by Energy Dispersive X-Ray Microanalysis (EDAX). High level of heavy metals such as $\mathrm{Al}, \mathrm{Si}, \mathrm{Mn}$ and Fe were found accumulated in Vellisnaria spiralis, Hydrilla verticillata and Azolla pinnata.

As the macrophytes concentrate great amount of various substances (e.g. metals) and are consequently useful indicators of local pollution, the aim of the present study was to assess the toxicity status induced by six heavy metals ( $\mathrm{Cd}, \mathrm{Co}, \mathrm{Cu}, \mathrm{Ni}, \mathrm{Pb}$ and $\mathrm{Zn})$ in selected plant parts (roots, stems, leaves) of eight native 


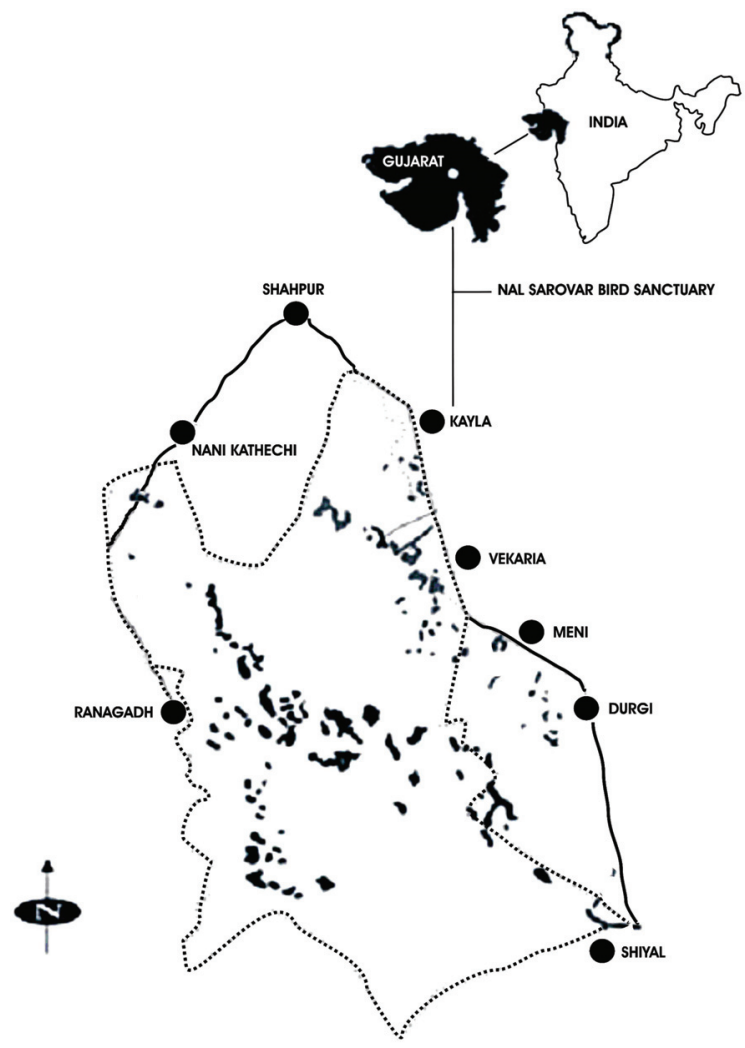

Fig. 1. Location map of Nal Sarovar Bird Sanctuary (NSBS).

aquatic macrophyte species (passive biomonitors) in comparison with sediment and water samples.

\section{MATERIALS AND METHODS}

Nal Sarovar Bird Sanctuary (NSBS) is located between $22^{\circ} 78^{\prime} \mathrm{N}$ to $22^{\circ} 96^{\prime} \mathrm{N}$ latitude and $71^{\circ} 92^{\prime} \mathrm{E}$ to $72^{\circ} 64^{\prime} \mathrm{E}$ longitude, falls in $4 \mathrm{~B}$ Gujarat-Rajwara biotic province of the semi arid lands of Central Gujarat, India. The details of NSBS have been depicted in table 1. The lake has more than 300 islets, occupies $120 \mathrm{~km}^{2}$, and is the principal source of food and fishing for local dependent communities of peripheral twelve villages. It receives water from two rivers: Brahmini and Bhogavo, carries household sewage and agricultural run-off from village pockets at north-western boundary. The waterflow pattern of the area is exhibited by gentle slope from north-west to south. No industrial effluent enters into the lake. The water temperature rises up to $35{ }^{\circ} \mathrm{C}$ during the month of May and falls below $15^{\circ} \mathrm{C}$ in January. The average rainfall is about $580 \mathrm{~mm}$ (Fig. 1). The marginal planes of NSBS support more than 260 species of aquatic birds besides two endangered mammalian species: Wild ass (Equus hemionus khur) and the threatened Blackbuck (Antilope cervicapra). The population estimation of waterfowl clearly signifies the lake as an internationally important wetland as per the criteria of Ramsar Convention. Accordingly, it is one of the proposed Ramsar Sites in India.
Tab. 1. Important characteristics of Nal Sarovar Bird Sanctuary.

\begin{tabular}{ll}
\hline Genesis & Late quaternary period \\
Latitude & $22078^{\prime} \mathrm{N}$ to $22096^{\prime} \mathrm{N}$ \\
Longitude & $71092^{\prime}$ E to $72064^{\prime} \mathrm{E}$ \\
Biotic province & 4B Gujarat-Rajwara (semi arid lands of \\
& Central Gujarat) \\
Area $\left(\mathrm{km}^{2}\right)$ & 120.89 \\
Slope & North-west to south \\
Shape & Ovo-ellispoidal \\
Maximum depth $(\mathrm{m})$ & 1.5 to 2.0 \\
Average depth $(\mathrm{m})$ & 1.0 \\
Number of islets & More than 300 \\
Temperature $\left({ }^{\circ} \mathrm{C}\right)$ & 15 to 35 \\
Average rainfall $(\mathrm{mm})$ & 580 \\
Wind velocity $\left(\mathrm{km} \mathrm{h}^{-1}\right)$ & 60 (during summer) \\
Planktons & 48 phytoplanktones \\
& 76 zooplanktons \\
Flora & 41 terrestrial plants \\
& 30 aquatic macrophytes \\
Fauna & 20 fishes, 11 herpetofauna \\
& 46 terrestrial birds, \\
& 260 waterfowl \\
Significance & 13 mammals \\
& Wetland of International Importance \\
\hline & Proposed Ramsar site \\
\hline
\end{tabular}

The National Wetland Committee also identifies NSBS as one of the important wetlands for evolving management action plan. Due to human interference, considerable changes occurred in its geomorphology, 
structure, water characteristics, hydrology and biotic composition in recent past.

\subsection{Field work}

\subsubsection{Water and sediment sampling}

Surface water and composite sediment samples were collected at random from different areas of the lake covering all directions during November 2004. Soon after collection, the water samples were filtered through $0.45 \mu \mathrm{m}$ (pore size) Millipore filter and preserved in plastic bottles by the addition of a few drops of nitric acid. Sediment samples were preserved in air-dry plastic bags. The samples were labeled carefully and brought to the laboratory for further analysis.

\subsubsection{Plant sampling}

Eight native aquatic macrophytes from the lake were selected as passive biomonitors for estimating the toxicity status induced by six heavy metals $(\mathrm{Cd}, \mathrm{Co}, \mathrm{Cu}$, $\mathrm{Ni}, \mathrm{Pb}$ and $\mathrm{Zn}$ ) and were collected in November 2004. The plant species selected were: Bergia odorata, Hydrilla verticillata, Ipomoea aquatica, Najas graminea, Nelumbo nucifera, Phragmites karka, Typha angustata and Vellisnaria spiralis. Healthy aquatic plants were collected by hand, washed with lake water to remove periphyton and sediment particles. Therefore, the element concentrations in the plant parts refer not only to tissue concentrations but also to adsorbed elements on part surfaces. The collected plant species were preserved in plastic bags, labeled carefully and brought to the laboratory. To avoid the introduction of metal contamination, polythene tools were used in sampling and storing the collected matrices (Allen 1989). Plant species were identified according to Shah (1962).

\subsection{Laboratory work}

\subsubsection{Chemical analysis of water, sediment and plant samples}

Sediment samples were air-dried, sieved through 2 $\mathrm{mm}$ governorates sieve and kept for analyses. Each aquatic plant species sorted into different parts: roots, stems and leaves. The $50 \mathrm{~g}$ of each fresh sample dried at $80{ }^{\circ} \mathrm{C}$ in hot air oven for $48 \mathrm{hrs}$. The samples of water, sediment and plant-parts were chemically analyzed for detection of heavy metals ( $\mathrm{Cd}, \mathrm{Co}, \mathrm{Cu}, \mathrm{Ni}, \mathrm{Pb}$ and $\mathrm{Zn}$ ). Accurately one $\mathrm{g}$ of dry powder of each sample was weighed, and digested with con. $\mathrm{HNO}_{3}, \mathrm{H}_{2} \mathrm{SO}_{4}$ and $\mathrm{H}_{2} \mathrm{O}_{2}$ (2:6:6) as prescribed by Saison et al. (2004). Towards the end of the digestion, the flasks were brought to near dryness. The solutions were made to 20 $\mathrm{ml}$ each in a measuring cylinder with doubled distilled water. The blanks were run with set, and the samples were analysed in Inductive Coupled Plasma Analyzer (ICPA) (Perkin-Elmer ICP Optima 3300 RL, U.S.A.) at Sophisticated Instrumentation Center for Applied Research and Testing (SICART), Vallabh Vidyanagar,
Gujarat. The concentration of heavy metals such as $\mathrm{Cd}$, $\mathrm{Co}, \mathrm{Cu}, \mathrm{Ni}, \mathrm{Pb}$ and $\mathrm{Zn}$ was analyzed and calculated in $\mathrm{mg} \mathrm{l}^{-1}$. Mean values of duplicate sub-samples of the water, sediment and plant samples were considered.

\subsection{Data analysis}

The mean values of heavy metals were calculated for water, sediment and plant samples. The unilateral $F$ test was carried out between heavy metal contents in roots, stems and leaves to check if significant differences exist between the accumulation rate of each metal and different plant parts. Pearson correlation coefficient analysis was done between metal-pairs in plants to check if differences exist between different metal combinations in either root, stem or leaf system. The products of the correlation coefficient $(r)$ were evaluated as follows:

(-1)-0.3: No correlation; 0.3-0.5: Low correlation; 0.50.7: Medium correlation; 0.7-0.9: High correlation; 0.9 1.0: Very high correlation.

The comparison of the concentration of an element in an aquatic organism with that of the same element in the water in which the organism lives. This is the ratio between the concentration of the element in the organism and that of in the water, which is known as Concentration Factor (De Bortoli et al. 1968). The Concentration Factor (C.F.) was calculated.

\section{RESULTS}

\subsection{Water and sediments}

The concentrations of the elements considered were far higher in the sediments than those calculated for the same elements in the lake water filtered through Millipore filter $(0.45 \mu \mathrm{m}$ opening size). Of the elements analyzed $\mathrm{Zn}$ was the most abundant both in sediments $\left(553.47 \mathrm{mg} \mathrm{l}^{-1}\right)$ and water $\left(94.03 \mathrm{mg} \mathrm{l}^{-1}\right)$, followed by Co with a concentration of $64.83 \mathrm{mg} \mathrm{l}^{-1}$ in the sediments and $17.58 \mathrm{mg}^{-1}$ in the water. Other metals $(\mathrm{Ni}, \mathrm{Cu}, \mathrm{Cd}$ and $\mathrm{Pb}$ ) exhibit the receding trend in both sediments and water. The values of the ratio between element concentrations in the sediments and those in the water were lower (1.15-5.89) for $\mathrm{Pb}, \mathrm{Cu}, \mathrm{Co}, \mathrm{Ni}$ and $\mathrm{Zn}$, whereas that of $\mathrm{Cd}$ was observed high $\left(25.78 \mathrm{mg} \mathrm{l}^{-1}\right)$ (Tab. 2, Fig. 2).

Tab. 2. Element concentration ratios between sediments and water.

\begin{tabular}{lccc}
\hline & $\begin{array}{c}\text { Sediment } \\
\left(\mathrm{mg} \mathrm{l}^{-1}\right)\end{array}$ & $\begin{array}{c}\text { Water } \\
\left(\mathrm{mg} \mathrm{l}^{-1}\right)\end{array}$ & Sediment/Water \\
\hline $\mathrm{Cd}$ & 8.83 & 0.34 & 25.78 \\
$\mathrm{Co}$ & 64.83 & 17.58 & 3.69 \\
$\mathrm{Cu}$ & 32.88 & 9.42 & 3.49 \\
$\mathrm{Ni}$ & 50.33 & 12.90 & 3.90 \\
$\mathrm{~Pb}$ & 5.59 & 4.87 & 1.15 \\
$\mathrm{Zn}$ & 553.47 & 94.03 & 5.89 \\
\hline
\end{tabular}




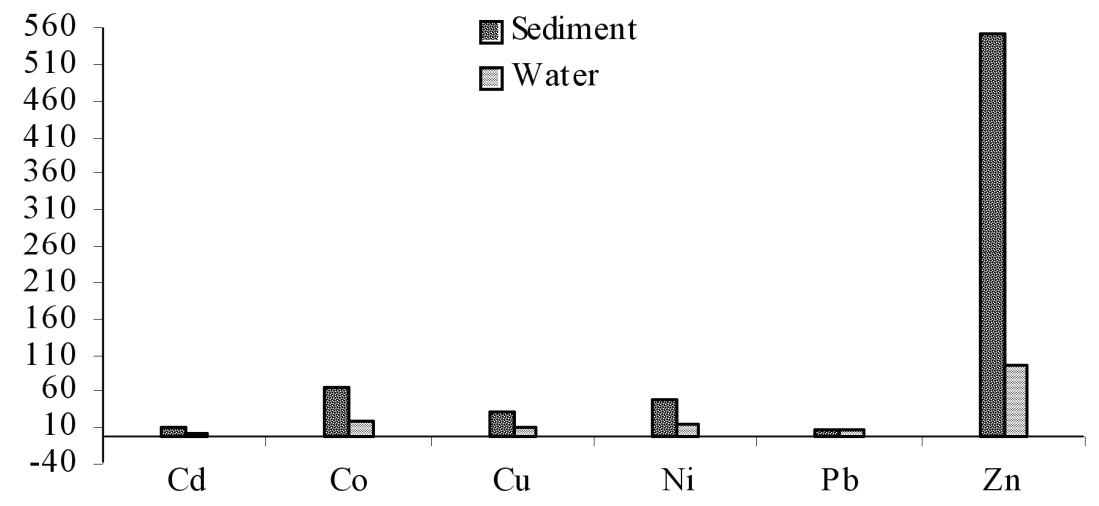

Fig. 2. Mean concentration $\left(\mathrm{mg} \mathrm{l}^{-1}\right)$ of six heavy metals in water and sediment samples of NSBS.

Tab. 3. Element concentration $\left(\mathrm{mg} \mathrm{l}^{-1}\right)$ in certain macrophyte species.

\begin{tabular}{lcccccc}
\hline & $\mathrm{Cd}$ & $\mathrm{Co}$ & $\mathrm{Cu}$ & $\mathrm{Ni}$ & $\mathrm{Pb}$ & $\mathrm{Zn}$ \\
\hline Bergia odorata & 0.40 & 2.62 & 27.75 & 23.01 & 4.11 & 128.63 \\
Hydrilla verticillata & 0.44 & 3.04 & 21.80 & 20.09 & 6.20 & 155.18 \\
Ipomoea aquatica & 0.21 & 10.48 & 7.41 & 7.95 & 2.67 & 639.04 \\
Najas graminea & 0.58 & 6.00 & 39.70 & 28.16 & 13.90 & 509.93 \\
Nelumbo nucifera & 0.59 & 1.68 & 23.20 & 20.50 & 5.28 & 221.03 \\
Phragmites karka & 0.74 & 7.59 & 18.99 & 15.10 & 2.87 & 168.59 \\
Typha angustata & 0.46 & 2.99 & 31.35 & 28.86 & 8.28 & 169.48 \\
Vellisnaria spiralis & 1.28 & 6.66 & 66.26 & 28.75 & 9.20 & 239.17 \\
Mean & 0.59 & 5.13 & 29.56 & 21.55 & 6.56 & 278.88 \\
$\mathrm{SD}$ & 0.32 & 3.04 & 17.56 & 7.38 & 3.78 & 188.99 \\
\hline & & & & & &
\end{tabular}

Tab. 4. Concentration factors calculated for the various species and elements.

\begin{tabular}{lccccccc}
\hline & $\mathrm{Cd}$ & $\mathrm{Co}$ & $\mathrm{Cu}$ & $\mathrm{Ni}$ & $\mathrm{Pb}$ & $\mathrm{Zn}$ & Mean \\
\hline Bergia odorata & 1.17 & 0.15 & 2.95 & 1.78 & 0.84 & 1.37 & 1.38 \\
Hydrilla verticillata & 1.28 & 0.17 & 2.31 & 1.56 & 1.27 & 1.65 & 1.38 \\
Ipomoea aquatica & 0.62 & 0.60 & 0.79 & 0.62 & 0.55 & 6.80 & 1.66 \\
Najas graminea & 1.72 & 0.34 & 4.21 & 2.18 & 2.85 & 5.42 & 2.79 \\
Nelumbo nucifera & 1.73 & 0.10 & 2.46 & 1.59 & 1.08 & 2.35 & 1.55 \\
Phragmites karka & 2.16 & 0.43 & 2.02 & 1.17 & 0.59 & 1.79 & 1.36 \\
Typha angustata & 1.34 & 0.17 & 3.33 & 2.24 & 1.70 & 1.80 & 1.76 \\
Vellisnaria spiralis & 3.78 & 0.38 & 7.03 & 2.23 & 1.89 & 2.54 & 2.98 \\
Mean & 1.73 & 0.29 & 3.14 & 1.67 & 1.35 & 2.97 & \\
SD & 0.95 & 0.17 & 1.86 & 0.57 & 0.78 & 2.01 & \\
\hline
\end{tabular}

\subsection{Macrophytes}

Table 3 shows the values of concentration of six elements in eight species of macrophytes. The mean concentration values of the elements in the plants decrease according to this sequence: $\mathrm{Zn}>\mathrm{Cu}>\mathrm{Ni}>\mathrm{Pb}$ $>\mathrm{Co}>\mathrm{Cd}$. Ipomoea sp. has the greatest capacity for concentrating trace element with highest concentration (639.04 $\mathrm{mg} \mathrm{l}^{-1}$ ) of $\mathrm{Zn}$ and lowest concentration of $\mathrm{Cd}$ (0.21 $\left.\mathrm{mg} \mathrm{l}^{-1}\right)$, followed by Najas, Vellisnaria, Nelumbo, Typha, Phragmites and Hydrilla spp. Conversely, Bergia sp. has the lowest number of trace element concentration with high concentration of $\mathrm{Zn}\left(128.63 \mathrm{mg} \mathrm{l}^{-1}\right)$ and low concentration of $\mathrm{Cd}\left(0.40 \mathrm{mg} \mathrm{l}^{-1}\right)$.

Table 4 gives values of Concentration Factor (C.F.) for each species and element. The mean C.F. value of the elements in the plants decrease according to this sequence: $\mathrm{Cu}>\mathrm{Zn}>\mathrm{Cd}>\mathrm{Ni}>\mathrm{Pb}>\mathrm{Co}$. This sequence, which is rather different from that of the mean concentrations of elements in the plants, reflects the capacity of the macrophytes to accumulate elements independently from their concentration in the water that is the regulation capacity of the plants. Mean concentration factor for the various elements calculated for Vallisneria sp. are generally rather high, followed by Najas and Typha spp., while those for Phragmites and Hydrilla spp. are lower than those of the other species.

At least, two sources of contamination are responsible for pollution in NSBS, namely agricultural run-off and household (sewage) effluents, coming through several drains alongwith washing, bathing, cattle wading and agricultural run-off from peripheral villages at 


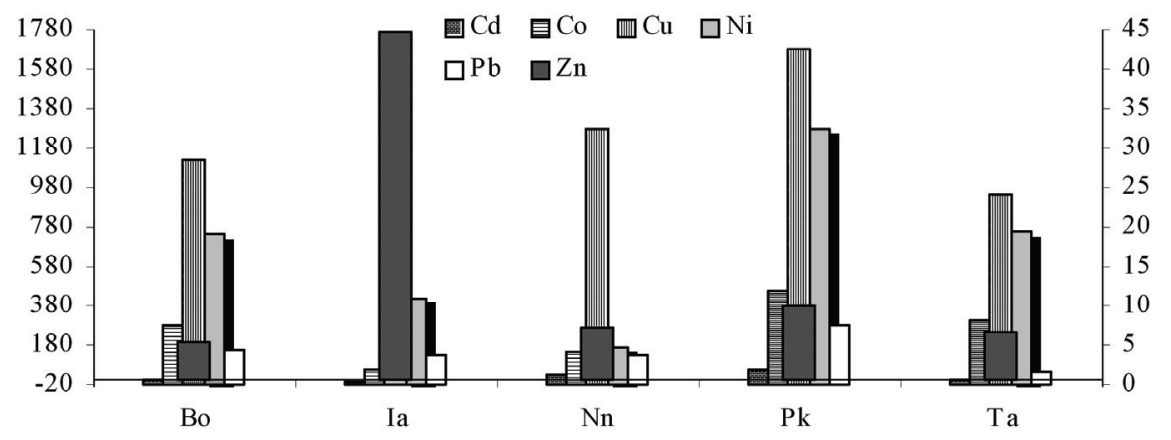

Fig. 3. Mean concentration $\left(\mathrm{mg} \mathrm{l}^{-1}\right)$ of six heavy metals in roots of five plant species from NSBS. $($ Bo $=$ Bergia odorata, Ia $=$ Ipomoea aquatica, $\mathbf{N} \mathbf{n}=$ Nelumbo nucifera, $\mathbf{P k}=$ Phragmites karka, $\mathbf{T a}=$ Typha angustata $)$.

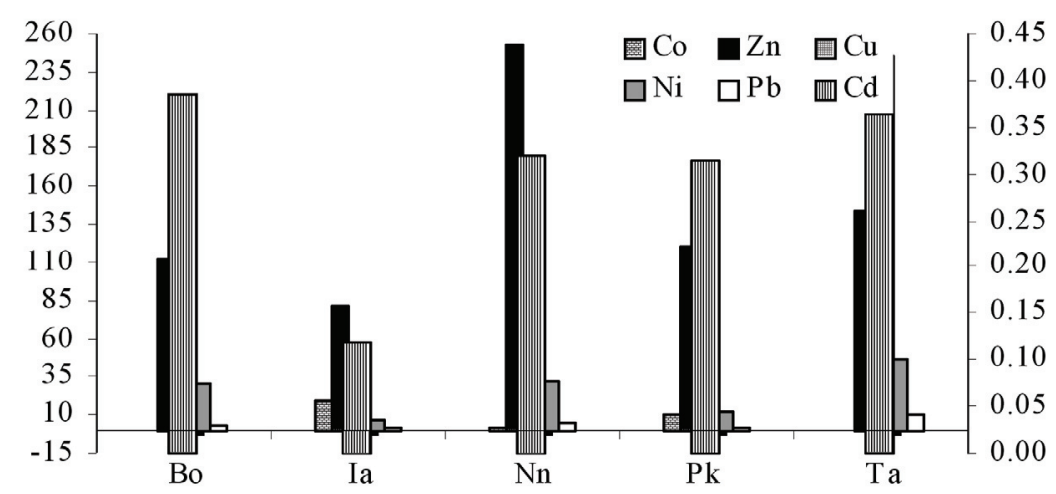

Fig. 4. Mean concentration $\left(\mathrm{mg} \mathrm{l}^{-1}\right)$ of six heavy metals in stems of five plant species from NSBS. $($ Bo $=$ Bergia odorata, Ia $=$ Ipomoea aquatica, $\mathbf{N n}=$ Nelumbo nucifera, $\mathbf{P k}=$ Phragmites karka, $\mathbf{T a}=$ Typha angustata $)$.

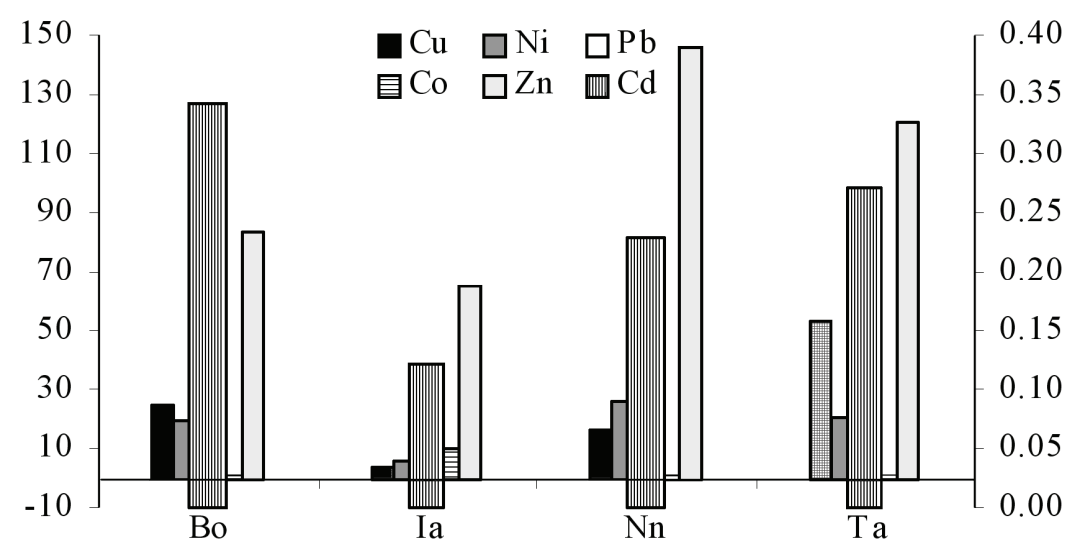

Fig. 5. Mean concentration $\left(\mathrm{mg} \mathrm{l}^{-1}\right)$ of six heavy metals in leaves of four plant species from NSBS. $($ Bo $=$ Bergia odorata, $\mathbf{I a}=$ Ipomoea aquatica, $\mathbf{N n}=$ Nelumbo nucifera, $\mathbf{T a}=$ Typha angustata $)$.

north-west boundary. Heavy metals are the most dangerous contaminants since they are persistent and accumulate in water, sediments and in tissues of the living organisms, through two mechanisms, namely "bioconcentration" (uptake from the ambient environment) and "biomagnification" (uptake through the food chain) (Lambou \& Williams 1980; Chaphekar 1991). The present results include assessment of six heavy metals $(\mathrm{Cd}$,
$\mathrm{Co}, \mathrm{Cu}, \mathrm{Ni}, \mathrm{Pb}$ and $\mathrm{Zn}$ ) and evaluation of their toxicity status in different plant parts of eight native aquatic plant species (Figs 3, 4, 5).

\subsubsection{Heavy metal pollution in plants}

The chemical analysis (for roots, stems and leaves) of five native plant species from NSBS was carried out. These species are: Bergia odorata, Ipomoea aquatica, 
Nelumbo nucifera, Phragmites karka and Typha angustata. Besides Hydrilla verticillata, Najas graminea and Vellisnaria spiralis were analysed intact without sorted into different parts due to their incoherent phenophases. All the selected aquatic macrophytes were collected mostly from all directions of NSBS from at least $0.5 \mathrm{~m}$ depth. Compared to the standard, normal and critical toxicity range of metals in all selected plants, the concentrations of $\mathrm{Cd}$ and $\mathrm{Pb}$ was observed within normal ranges, while that of $\mathrm{Co}, \mathrm{Cu}$ and $\mathrm{Ni}$ were registered within the critical ranges. However, $\mathrm{Zn}$ showed the highest concentration and alarming toxicity levels, which is considered as one of the most hazardous pollutants in Nal Sarovar Bird Sanctuary (Tab. 5).

Tab. 5. Ranges of heavy metals contents and toxicity status in the tested plant species, compared with normal and critical ranges in plants. * Data after Kabata-Pendias \& Pendias (1992).

\begin{tabular}{lcccc}
\hline & $\begin{array}{c}\text { Mean range } \\
\left(\mathrm{mg} \mathrm{l}^{-1}\right)\end{array}$ & $\begin{array}{c}\text { Normal range } \\
\left(\mathrm{mg} \mathrm{l}^{-1}\right)^{*}\end{array}$ & $\begin{array}{c}\text { Critical range } \\
\left(\mathrm{mg} \mathrm{l}^{-1}\right)^{*}\end{array}$ & Toxicity status \\
\hline $\mathrm{Cd}$ & $0.12-1.89$ & $0.1-2.4$ & $10-30$ & Normal \\
$\mathrm{Co}$ & $0.09-19.10$ & $0.75-1.07$ & $1-8$ & Critical \\
$\mathrm{Cu}$ & $3.85-53.35$ & $7.53-8.44$ & $25-90$ & Critical \\
$\mathrm{Ni}$ & $4.68-46.80$ & $0.89-2.04$ & $10-50$ & Critical \\
$\mathrm{Pb}$ & $1.11-12.57$ & $0.2-20$ & $30-300$ & Normal \\
$\mathrm{Zn}$ & $64.25-1771.39$ & $1-400$ & $100-400$ & Critical \\
\hline
\end{tabular}

The concentrations of $\mathrm{Cd}$ and $\mathrm{Pb}$ fall within the normal range. All observed values of $\mathrm{Cd}(0.12-1.89 \mathrm{mg}$ $\left.\mathrm{l}^{-1}\right)$ and $\mathrm{Pb}\left(1.11-12.57 \mathrm{mg} \mathrm{l}^{-1}\right)$ falls within the standard normal range $0.1-2.4 \mathrm{mg} \mathrm{l}^{-1}$ and 30-300 $\mathrm{mg} \mathrm{l}^{-1}$, respectively, in studied plants, whereas concentration of $\mathrm{Co}$ (0.09-19.10 $\left.\mathrm{mg} \mathrm{l}^{-1}\right), \mathrm{Cu}\left(3.85-53.35 \mathrm{mg} \mathrm{l}^{-1}\right), \mathrm{Ni}(4.68-$ $\left.46.80 \mathrm{mg} \mathrm{l}^{-1}\right)$ and $\mathrm{Zn}\left(64.25-1771.39 \mathrm{mg} \mathrm{l}^{-1}\right)$ was recorded within critical ranges, $1-8 \mathrm{mg} \mathrm{l}^{-1}, 25-90 \mathrm{mg} \mathrm{l}^{-1}$, $10-50 \mathrm{mg} \mathrm{l}^{-1}$ and 100-400 $\mathrm{mg} \mathrm{l}^{-1}$, respectively.

\subsubsection{Zinc (Zn) in plants}

Compared with the standard critical range of $\mathrm{Zn}$ (100-400 $\left.\mathrm{mg} \mathrm{l}^{-1}\right)$, a critical amount (1771.39 $\left.\mathrm{mg} \mathrm{l}^{-1}\right)$ existed in roots of Ipomoea sp. The same applies to stems and leaves of Nelumbo sp., $253.43 \mathrm{mg} \mathrm{l}^{-1}$ and $145.53 \mathrm{mg} \mathrm{l}^{-1}$, respectively. Thus $\mathrm{Zn}$ seems to be the most hazardous pollutant in NSBS, since it reached extremely high concentrations and may cause serious toxicity in most of the investigated plant species.

Accumulation pattern of heavy metals in root, stem and leaf systems: Applying unilateral $F$-test on the concentrations of each metal (separately in roots against stems and leaves), indicated significant differences only for $\mathrm{Zn}(p<0.05)$ as follows:

Metal: $\quad \mathrm{Cd} \quad \mathrm{Co} \quad \mathrm{Cu} \quad \mathrm{Ni} \quad \mathrm{Pb} \quad \mathrm{Zn}$

$\begin{array}{lllllll}F \text {-value: } & 0.007 & 0.160 & 0.774 & 0.444 & 0.288 & 0.001 *\end{array}$

Based on the above results, it is obvious that Zinc seems to accumulate with more tendencies towards roots than stems of the tested species. The output of Pearson correlation coefficient analysis on combinations of different metal-pairs which are present together in either roots, stems or leaves of the tested plant species and showed medium + ve correlation $(r=0.5-0.7)$ between only a single metal pair $(\mathrm{Cu}$ and $\mathrm{Ni})$, high + ve correlation $(r=0.7-0.9)$ between $\mathrm{Cu}$ and $\mathrm{Cd}, \mathrm{Ni}$ and $\mathrm{Cd}$, $\mathrm{Pb}$ and $\mathrm{Cd}$, and $\mathrm{Cu}$ and $\mathrm{Pb}$ metal pairs, and very high + ve correlation $(r>0.9)$ between $\mathrm{Ni}$ and $\mathrm{Pb}$ metal pairs (Tab. 6). These results indicated that both root and stem systems may have a kind of natural controlling mechanism regarding the quantity of specific metals taken from the ambient environment, but they don't have controlling mechanism to suppress the combination between specific metal-pairs in their tissues (Ravera et al. 2003).

Tab. 6. Correlation coefficient between concentrations of heavy metal-pairs in root, stem and leaf systems of plant species. * Medium Correlation $(r=0.5-0.7)$; ** High Correlation $(\mathrm{r}=0.7-0.9)$; *** Very High Correlation $(r>0.9)$.

\begin{tabular}{lccc}
\hline \multirow{2}{*}{$\begin{array}{l}\text { Analysis } \\
\text { metal-pair }\end{array}$} & \multicolumn{3}{c}{ Correlation Coefficient $(r)$} \\
\cline { 2 - 4 } & Root system & Stem system & Leaf system \\
\hline $\mathrm{Zn} \times \mathrm{Cd}$ & -0.387 & 0.339 & 0.274 \\
$\mathrm{Cu} \times \mathrm{Cd}{ }^{* *}$ & 0.890 & 0.754 & 0.597 \\
$\mathrm{Ni} \times \mathrm{Cd} * *$ & 0.496 & 0.841 & 0.702 \\
$\mathrm{Ni} \times \mathrm{Zn}$ & -0.279 & 0.459 & 0.864 \\
$\mathrm{Co} \times \mathrm{Cd}$ & 0.639 & -0.906 & -0.860 \\
$\mathrm{~Pb} \times \mathrm{Cd} * *$ & 0.721 & 0.675 & 0.296 \\
$\mathrm{Zn} \times \mathrm{Cu}$ & -0.710 & 0.326 & 0.416 \\
$\mathrm{Zn} \times \mathrm{Ni}$ & -0.279 & 0.459 & 0.864 \\
$\mathrm{Zn} \times \mathrm{Co}$ & -0.644 & -0.589 & -0.727 \\
$\mathrm{Zn} \times \mathrm{Pb}$ & -0.053 & 0.276 & 0.714 \\
$\mathrm{Cu} \times \mathrm{Ni} *$ & 0.548 & 0.556 & 0.494 \\
$\mathrm{Cu} \times \mathrm{Co}$ & 0.777 & -0.846 & -0.647 \\
$\mathrm{Cu} \times \mathrm{Pb} * *$ & 0.689 & 0.242 & 0.874 \\
$\mathrm{Ni} \times \mathrm{Co}$ & 0.905 & -0.889 & -0.960 \\
$\mathrm{Ni} \times \mathrm{Pb} * * *$ & 0.588 & 0.932 & 0.569 \\
$\mathrm{Co} \times \mathrm{Pb}$ & 0.503 & -0.664 & -0.590 \\
\hline
\end{tabular}

\subsubsection{Overall chain-transport mechanism of metals}

Overall study reflects the transport mechanism of metals from abiotic environment (soil) to biotic environment (macrophyte) and their accumulation in various parts of aquatic plants. The transport mechanism and accumulation pattern of heavy metals (mean concentration) can be elaborated as follows: Sediment $>$ Root system $>$ Stem system $>$ Leaf system (Fig. 6).

Species proposed as biomonitors / biofilters for heavy metals: The information of metals versus species (arranged in a decreasing order) containing metals higher than the minimum critical limits (Kabata-Pendias \& Pendias 1992) is as follows.

Metal proposed for biomonitors / biofilters

$$
\begin{gathered}
\mathrm{Zn}(\text { Ipomoea }>\text { Najas }>\text { Vellisnaria }) \\
\mathrm{Cu}(\text { Vellisnaria }>\text { Najas }>\text { Typha }) \\
\mathrm{Ni}(\text { Typha }>\text { Vellisnaria }>\text { Najas })
\end{gathered}
$$

Based on the above results, it was concluded that the three native aquatic plant species (Ipomoea, Vellisnaria 


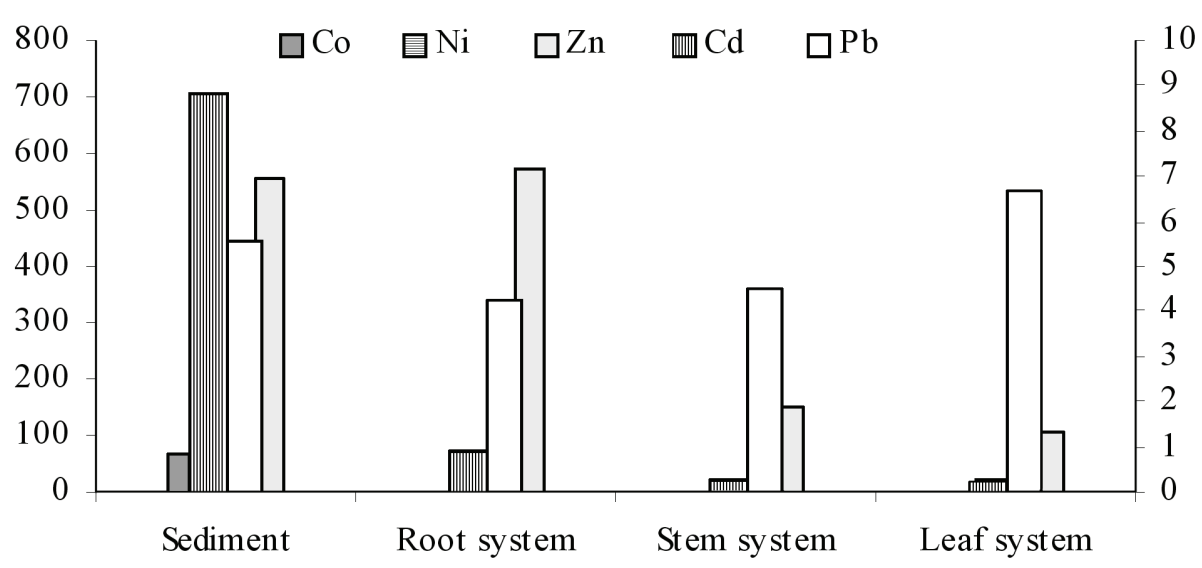

Fig. 6. Mean concentration $\left(\mathrm{mg} \mathrm{l}^{-1}\right)$ of six heavy metals in sediment and plan parts from NSBS.

and Typha) accumulated heavy metals in much higher concentrations. Perhaps, it might be the reason that these three species are more efficient than the other native species in uptake of metals. Such aquatic macrophytes could also be used as "biomonitors / biofilters" as compared to other native aquatic macrophyte species.

\section{DISCUSSION AND CONCLUSIONS}

The aquatic plants growing in the study area exhibit different trace element concentrations, depending on the plant organ, and both the sampling time and the sampling site (Baldantoni et al. 2005). Roots of aquatic plants absorb heavy metals from the interstitial water (or pore water) and accumulate high concentrations (Baldantoni et al. 2004). Similarly our findings reveal the higher concentrations of all the studied heavy metals in roots of Ipomoea and Phragmites spp. The stems and/or leaves of submerged plants accumulate lower concentrations of trace elements than roots. The results of the present work are also well-coincided with this, elaborated by low metal concentrations in stem and leaf systems of the plants (Nirmal Kumar \& Kumar 1989; Baldantoni et al. 2005). Thus among the investigated species, Ipomoea and Phragmites spp. appears to be the best monitoring species due to their availability throughout the year in NSBS.

The present study shows that the concentrations of the metals (in sediments and plant tissues) could be arranged in a decreasing order as follows: $\mathrm{Zn}>\mathrm{Cu}>\mathrm{Ni}$ $>\mathrm{Co}>\mathrm{Pb}>\mathrm{Cd}$. The ratio of these metals was two times higher in the sediments than in studied aquatic macrophytes. This agrees with previous findings of Ramdan (2003). Accordingly, the studied samples from NSBS could be arranged in a decreasing order based on their content of heavy metals as follows: Sediment $>$ Root system $>$ Stem system $>$ Leaf system. LovettDoust et al. (1994) estimated that the accumulation levels of organochlorine pollutants (PCB) in aquatic ecosystems may be higher in sediments than in plants. The highest level of $\mathrm{Cu}$ in our study might be due to down- stream flow of River Brahmani at north-west coming through sewage outfall from upstream, which is an important source of contamination in the lake, which agrees with the findings of Jones et al. (1991) for a lake in Wales, emphasizing that existing agricultural practices on soils around the lake may also be responsible for high $\mathrm{Cu}$ concentration measured in the sediments of Lake. This also largely agrees with the findings of Siegel et al. (1994) on Ginka sub-basin, south of Lake Manzala. Thus, the following decreasing order of the studied metals in Lake NSBS was based on the degree of toxicity level in both cases of plants and sediments: $\mathrm{Zn}>\mathrm{Cu}>\mathrm{Ni}$. The above sequence agrees with the findings of Ramdan (2003) and Siegel et al. (1994), who have worked on Lake Manzala, Nile Delta, Egypt. The native species may become tolerant to heavy metals and they may metabolize and secrete them (Abdel Moati 1985). We obtained results interpreting that the concentrations of heavy metals were much lower in tissues of the native aquatic plant species than in the sediments.

Although our results showed that the toxicity status of the studied heavy metals (except Zinc) are not very alarming at Lake NSBS in the present time, as outlined by Ramadan \& Mekki (1996). We recommend that combating all kinds of pollution in Lake NSBS through prevention, controlling or by applying fine treatments on the drainage loads which discharge into the lake. Well-designed action plans should be developed, strongly supported and strictly executed within intensive rehabilitation programs. Because of the great importance of Lake NSBS, the threatened components of its food web should immediately be saved, starting by its physical elements and primary producers and terminating by man. That is because human populations of the twelve surrounding villages depend mostly on the food and fish produced from Lake NSBS.

\section{ACKNOWLEDGEMENTS}

We are grateful to "Charotar Ratna" and "Shalin Manav Ratna" Dr. C. L. Patel, Chairman, Charutar 
Vidya Mandal (CVM), Vallabh Vidynagar, Gujarat, India, for being a constant source of inspiration, initiation and motivation to carry out the work, without his initiative, this work would not have been possible. Thanks are also due to immense assistance of Dr. Gokul Patel and Mr. Tiwari in chemical analyses of samples using Inductive Coupled Plasma Analyzer (ICPA) in Sophisticated Center for Applied Research and Testing (SICART), Vallabh Vidyanagar, Gujarat, India.

\section{REFERENCES}

Abdel-Moati, A.R. 1985. Studies on the Chemistry of Lake Manzala Waters, Egypt. Ph.D. Thesis, Faculty of Science, Alexandria University.

Allen, S.E. 1989. Chemical Analysis of Ecological Materials. 2nd Ed. Blackwell Scientific Publications. Oxford.

Baldantoni, D., A. Alfani, P. Di Tommasi, G. Bartoli \& A. De Santo. 2004. Assessment of macro and microelement accumulation capability of two aquatic plants. Environ. Pollut., 130: 149-156.

Baldantoni, D., G. Maisto, G. Bartoli \& A. Alfani. 2005. Analyses of three native aquatic plant species to assess spatial gradients of lake trace element contamination. Aquat. Bot., 83: 48-60.

Chaphekar, S.B. 1991. An overview on bioindicators. J. Env. Biol., 12: 163-168.

De Bortoli, M., P. Gaglione, A. Malvicini \& C. Polvani. 1968. Concentration factors for strontium and caesium in fish of the lakes in the region of Varese (Northern Italy). Giorn. Fisica Sanit. Radioprot., 12: 324-331.

Dunbabin, J.S. \& K.H. Bowmer. 1992. Potential use of constructed wetlands for treatment of industrial wastewaters containing metals. Sci. Total Environ., 111: 151-168.

Jackson, L.J. 1998. Paradigms of metal accumulation in rooted aquatic vascular plants. Sci. Total Environ., 219: 223-231.

Jones, R., F.M. Chambers \& K. Benson-Evans. 1991. Heavy metals $(\mathrm{Cu}$ and $\mathrm{Zn})$ in recent sediments of Ilangrose Lake, Wales: non-ferrous smelting, Napoleon and the price of wheat - a plaeoecological study. Hydrobiology, 214: 149154.

Kabata-Pendias, A. \& H. Pendias, 1992. Trace Elements in Soils and Plants. 2nd ed. CRC Press. Boca Raton, Fla.
Lambou, V.W. \& L.R. Williams. 1980. Biological monitoring of hazardous wastes in aquatic systems. Second Interagency Workshop on in-Situ Water Sensing: Biological Sensors, Pensacola Beach, Florida: 11-18.

Lovett-Doust, J., M. Schmidt \& L. Lovett-Doust. 1994. Biological assessment of aquatic pollution: A review with emphasis on plants as biomonitors. Biol. Rev., 69: 147186.

Nirmal Kumar, J.I., S. Sreenivas \& B.C. Rana. 1989. EDAXanalysis of mud of four ponds from Central Gujarat. Ind. Bot. Contr., 6: 75-76.

Pip, E. \& J. Stepaniuk. 1992. Cadmium, copper and lead in sediments and aquatic macrophytes in the Lower Nelson River System., Manitoba, Canada. I. Interspecific differences and macrophyte - sediment relations. Arch. Hydrobiol., 124: 337-355.

Ramadan, A.A. \& L. Mekki. 1996. Studies on Higher Plant Communities in Lake Manzala. Report for Suez Canal Univ., Ismailia, Egypt (Unpublished).

Ramdan, A.A. 2003. Heavy metal pollution and biomonitoring plants in Lake Manzala, Egypt. Pak. J. Biol. Sci., 6 (13): 1108-1117.

Rana, B.C. \& J.I. Nirmal Kumar. 1988. Energy Dispersal Analysis of X-rays of certain aquatic macrophytes. Ind. $J$. Weed Sci., 20: 46-49.

Ravera, O., R. Cenci, G.M. Beon, M. Dantas, \& P. Lodigiani. 2003. Trace element concentrations in freshwater mussels and macrophytes as related to those in their environment. J. Limnol., 62 (1): 61-70.

Saison, C., C. Schwartz \& J.L. Morel. 2004. Hyperaccumulation of metals by Thlaspi caerulescens as affected by root development and $\mathrm{Cd}-\mathrm{Zn} / \mathrm{Ca}-\mathrm{Mg}$ interactions. Intl. J. Phytol., 6 (1): 49-61.

Shah, G. L. 1978. Flora of Gujarat State. Vols. I \& II. University Press. S. P. University. Vallabh Vidyanagar, Gujarat, India.

Siegel, F.R., M.I. Slaboda \& D.J. Stanely, 1994. Metal pollution loading, Manzalah lagoon, Nile delta, Egypt: Implications for aquaculture. Environmental Geology, 23: 8998.

Sinicrope, T.L., R. Langis, R.M. Gersberg, M.J. Busnardo \& J.B. Zedler. 1992. Metal removal by wetland mesocosms subjected to different hydroperiods. Ecol. Eng., 1: 309322 . 